\title{
EKSISTENSI MAHASISWI DALAM BERORGANISASI DI LINGKUNGAN FAKULTAS PENDIDIKAN ILMU PENGETAHUAN SOSIAL UNIVERSITAS PENDIDIKAN INDONESIA
}

\author{
Zaenal Mustopa, \\ SMA Negeri 3 Purwakarta \\ E-mail: zaenal.mustopa@student.upi.edu
}

\begin{abstract}
This study is based on the domination of men in a strategic position in organization at the Faculty of Social Science Education. This research is aimed at give a comprehensive depiction about women existence in organization. The research utilizes descriptive method with qualitative approach. Women and men existence in organization is considered equal; however in the distribution of tasks, women' stereotype can't be completely detached. Women's motivation is gain experiences to support their academic and social life. Women accesibility in holding a strategic position is open. However, to hold a leading role, there is an influence from the perspective of men's masculinity. The problems occurred to women in organization are biological factor (menstruation), limited access and conflict. To release the biological factor, women consume the pain killer, while to solve the problem of limited acess they coordinate and cooperate and to solve the conflict, they discuss with the people related conflict to get mutual agreement.
\end{abstract}

Keywords: Women, existence, organization, gender

\begin{abstract}
ABSTRAK
Penelitian ini dilatarbelakangi adanya dominasi laki-laki dalam menempati posisi strategis dalam organisasi kemahasiswaan di Fakultas Pendidikan IImu Pengetahuan Sosial. Tujuan dari penelitian memperoleh gambaran yang komprehensif mengenai eksistensi mahasiswi dalam berorganisasi. Penelitian ini menggunakan metode deskriptif dan pendekatan kualitatif. Peran mahasiswi dalam berorganisasi dianggap penting namun dalam pembagian peran mahasiswi belum bisa sepenuh terlepas dari stereotip. Motivasi mahasiswi dalam berorganisasi, yaitu untuk memperoleh pengalaman berorganisasi yang menunjang kegiatan akademik dan kehidupan di masyarakat kelak. Aksesibilitas mahasiswi dalam menempati posisi strategis terbuka. Namun untuk menduduki posisi ketua masih ada pengaruh stereotip bahwa ketua identik dengan sifat maskulinitas yang dimiliki laki-laki. Kendala yang ditemui dalam berorganisasi yaitu
\end{abstract}


faktor biologis (menstruasi), keterbatasan langkah, dan konflik, upaya dalam mengatasi kendala tersebut di antaranya meminum pereda nyeri, melakukan koordinasi dan diskusi untuk memperoleh solusi yang disepakati bersama.

Kata Kunci: Eksistensi, Mahasiswi, organisasi, gender

\section{PENDAHULUAN}

Organisasi kemahasiswaan pada umumnya tidak hanya beranggotakan kaum laki-laki, tentunya kaum perempuan dalam konteks ini adalah mahasiswi juga turut berperan aktif untuk menghidupkan organisasi. Kerjasama adalah salah satu kunci sebuah organisasi mahasiswa dapat berjalan sesuai dengan tujuan organisasi. Kerjasama yang dimaksud tentunya tidak diskriminatif pasalnya realitas yang ada setiap manusia memiliki sisi keunikannya masingmasing, baik itu secara fenotif maupun genotif.

Lahirnya generasi penerus dan pelurus bangsa lahir dari rahim seorang perempuan. Namun pengorbanannya yang begitu besar dan tidak semudah membalikkan telapak tangan, tidak berbanding lurus dengan status yang mereka peroleh. Konstruksi sosial baik dari keluarga sebagai unit terkecil maupun masyarakat selalu mengidentikkan perempuan sebagai makhluk kedua setelah laki-laki. Status sebagai makhluk kedua ini semakin dipertegas dengan adanya kecenderungan streotip bahwa perempuan adalah kaum yang ditempatkan pada urusanurusan domestik seperti mengelola rumah, memasak dan reproduksi sedangkan kaum laki-laki berurusan dengan kegiatan publik.

Perbedaan gender nampaknya masih menjadi persoalan hangat dalam struktur sosial kehidupan di masyarakat, hal ini tak terlepas dari budaya patriaki yang melekat di sebagian besar masyarakat. Budaya patriaki menjadi salah satu simbol kuatnya dominasi laki-laki terhadap perempuan dalam setiap sendi-sendi kehidupan sejalan dengan pernyataan berikut bahwa "patriaki dapat diartikan keadaan masyarakat yang menempatkan kedudukan dan posisi laki-laki lebih tinggi dari pada perempuan dalam segala aspek kehidupan sosial, budaya dan ekonomi"(Pinem dalam Aritonang, 2010, hlm. 8).

Pada dasarnya masyarakat itu sendiri berdinamika seiring dengan perkembangan zaman. Namun perihal cara pandang terhadap perempuan belum menunjukan perubahan yang menguntungkan bagi kaum perempuan pasalnya nilai kultural patriaki masih begitu kuat sehingga anggapan yang secara turun temurun menempatkan perempuan pada urusan rumah tangga atau kegiatan domestik. Tradisi yang secara turun temurun menjadi konstruksi terhadap persepsi masyarakat bahwa perempuan tidak perlu mengenyam pendidikan tinggi-tinggi karena pada akhirnya mereka akan diperistri dan mempunyai anak serta mengurus keperluan keluarga. Tanpa disadari persepsi ini terinternalisasi pada setiap generasi sehingga menjadi sebuah konsensus. Pada tataran kehidupan organisasi di kalangan mahasiswa 
juga tidak dapat terlepas dari pengaruh budaya patriaki pasalnya keterlibatan perempuan dalam organisasi terbatas pada ranah domestik sejalan dengan penelitian terdahulu mengungkapkan bahwa "partisipasi perempuan dalam berorganisasi hanya sedikit yang terlibat dalam struktur dan dapat dipastikan posisi tersebut menempati posisi yang identik dengan streotipe pekerjaan domestik seperti bendahara dan sekretaris" (Wahyuni dan Hidayah , 2014, hlm.6).

Ketertarikan peneliti terhadap permasalahan ini didasari adanya fenomena dominasi perempuan secara kuantitas di Fakultas Pendidikan IImu Pengetahuan Sosial. Namun dalam tataran organisasi di kalangan mahasiswa justru yang mendominasi jabatan-jabatan struktural yang strategis adalah lakilaki sedangkan perempuan ditempatkan pada posisi internal atau domestik. Sebagai sebuah contoh program studi Pendidikan Sosiologi mayoritas mahasiswanya adalah perempuan terhitung dari angkatan 2015 sampai dengan 2012 perempuan berjumlah 187 sedangkan laki-laki 74 .

Mengingat begitu banyaknya mahasiswi sedangkan dalam tataran berorganisasi dari 11 Himpunan yang ada di Fakultas Pendidikan IImu Pengetahuan Sosial jabatan-jabatan strategis ditempati mahasiswa, padahal di lingkungan fakultas ini mahasiswi berpotensi menempati posisi-posisi strategis. Atas dasar itu peneliti beranggapan mesti ada kesetaraan gender dalam kegiatankegiatan mahasiswa di lingkungan Fakultas Pendidikan IImu
Pengetahuan Sosial Universitas Pendidikan Indonesia dan dalam konteks ini adalah kesetaraan gender dalam berorganisasi.

\section{METODE}

Eksistensi mahasiswi dalam berorganisasi diteliti melalui pendekatan kualitatif. Pendekatan ini dipilih karena permasalahan yang diteliti tidak dapat diukur secara matematis, teori, serta hipotesis dan melalui proses pengukuran seperti pendekatan kuantitatif. Mahasiswi dalam berorganisasi menjadi isu penting pada penelitian ini. Maka dari itu peneliti terlibat langsung dengan subjek penelitian guna mendapatkan informasi dan mencapai tujuan penelitian yang telah dirumuskan.

Peneliti berusaha memahami kegiatan berorganisasi mahasiswi di lingkungan Fakultas Pendidikann IImu Pengetahuan Sosial Universitas Pendidikan Indonesia melalui pengalaman terlibat langsung dengan subjek penelitian, peneliti menuangkan hasil pengamatan dari pengalaman tersebut ke dalam kata-kata atau deskripsi beserta gambar-gambar dan dokumentasi pada saat observasi langsung.

Pengumpulan informasi dalam penelitian ini meliputi wawancara, observasi partipasi, studi dokumentasi dan studi literatur. Pada saat mencari informasi di lapangan peneliti mengamati dan mengajukan pertanyaan-pertanyaan terbuka seputar permasalahan yang sedang digali. Selain itu peneliti juga mengabadikan beberapa dokumentasi baik itu berupa suara maupun gambar. 
Pada penelitian ini yang menjadi subjek/partisipan penelitian adalah mahasiswi yang menjadi pengurus Himpunan Mahasiswa di lingkungan Fakultas Pendidikan IImu Pengetahuan Sosial Universitas Pendidikan Indonesia. Hal ini didasarkan bahwa dalam penelitian kualitatif yang menjadi sumber informasi dipilih secara "pursposive. $\mathrm{Hal}$ ini didasarkan menurut Bungin (2011,hlm.107) mengemukakan bahwa:

Purposive sampling adalah salah satu strategi menentukan informan yang paling umum di dalam penelitian kualitatif, yaitu menentukan kelompok peserta yang menjadi informan sesuai dengan kriteria terpilih yang relevan dengan masalah penelitian tertentu. Contoh dari penggunaan prosedur purposive ini adalah antara lain dengan key person.

Sedangkan teknik analisis data menggunakan data reduksi (data reduction), Penyajian Data (Data Display), Kesimpulan (Conclusion Drawing Verification). Data yang telah didapatkan akan diolah dan dicek kebenaran datanya, peneliti melalukan pengecekan kebenaran data dengan cara yang dikemukakan Sugiyono (2009, hlm 129) bahwa "member check adalah proses pengecekan data yang diperoleh peneliti kepada pemberi data."

\section{HASIL DAN PEMBAHASAN \\ Peran Mahasiswi dalam Berorganisasi}

Keberadaan peran mahasiswi dan dalam organisasi di lingkungan
Fakultas Pendidikan IImu Pengetahuan sosial sama pentingnya dengan mahasiswa. Keduanya bekerjasama saling melengkapi dan menyeimbangkan satu sama lain untuk perkembangan organisasi guna mencapai tujuan organisasinya. Hal tersebut menunjukkan adanya sikap asosiatif dalam berorganisasi sesuai dengan pernyataan pemikiran berikut bahwa dalam berorganisasi bukanlah suatu usaha yang dilakukan secara perorangan atau individual, melainkan suatu usaha yang dilakukan dua orang atau lebih secara berkelompok melalui proses yang bersifat asosiatif yakni dengan ditunjukkan adanya suatu kerjasama antar individu guna mencapai tujuan bersama dalam berorganisasi (Liliweri,1997,hlm.2).

Peran mahasiswi dalam berorganisasi tidak terlepas dari pengaruh proses sosialisasi yang diterimanya. Dalam konteks organisasi, sosialisasi dilakukan melalui proses kaderisasi dimana setiap anggota dibina agar dapat menyesuaikan dengan lingkungan organisasi dan agar senantiasa memahami segala hal yang berkaitan dengan organisasinya karena memang sosialisasi adalah proses belajar untuk menyesuaikan diri sekaligus pembentukkan sikap individu agar senantiasa berperilaku sesuai dengan kebiasaan, aturan-aturan dan normanorma yang berlaku dalam suatu kelompok sehingga indvidu-individu tersebut dapat diterima dan menjadi bagian dari kelompok tersebut (Abercombie dkk, 2010, hlm.529).

Penentuan peran mahasiwi dalam berorganisasi masih bersifat konvensional, yakni dengan 
memandang gender tertentu sebagai dasar pembagian peran dalam berorganisasi. Penentuan kedudukan dan peran mahasiswi berdasarkan gender ini merupakan sebuah pandangan atas dasar konstruksi sosial yang berkembang secara turun temurun dalam organisasi tersebut bahwa ada bagian-bagian tertentu yang hanya diperuntukkan salah satu jenis kelamin atau dapat dibilang bias gender. Hal tersebut sebagaimana yang diungkapkan Handayani dan Sugiharti (2008, hlm.5) tentang konsep gender, yaitu "kontruksi sosial budaya suatu kelompok atau masyarakat dari hasil interpretasi kodrat yang melekat pada laki-laki dan perempuan untuk membedakan peran dan fungsi keduanya di masyarakat".

Hal ini menggambarkan masih adanya nilai-nilai sosial budaya yang bersifat tradisional yakni unsur budaya patriaki dalam berorganisasi yaitu mendahulukan laki-laki dalam urusan tertentu dan menomorduakan atau memarginalkan perempuan. Sejalan dengan apa yang dikemukakan Astuti (2013, hlm.14) bahwa budaya patriaki adalah suatu sistem yang hidup di masyarakat, dimana adanya pengutamaan laki-laki sebagai pihak superodinat dan mengesampingkan perempuan sebagai pihak yang subordinat. Pada kegiatan berorganisasi di lingkungan Fakultas Pendidikan IImu Pengetahuan Sosial dalam hal pembagian peran antara mahasiswi dan mahasiswa tidak dapat dihindarkan dari kecenderungan persepsi terhadap gender dan stereotip yang menempatkan posisi tertentu untuk jenis kelamin tertentu sebagai akibat adanya budaya patriaki yang lumayan mengakar di organisasi yang tersosialisasikan secara turuntemurun sehingga membentuk cara berpikir atau cara pandang seseorang dalam organisasi tersebut. Hal ini ditunjukkan dari hasil temuan secara empiris bahwa adanya suatu persepsi mahasiswi maupun mahasiswa yang cenderung bersifat stereotip terhadap peran-peran yang identik dengan bagian internal dalam suatu kepengurusan di organisasi seperti posisi sekretaris dan bendahara. Konstruksi sosial terhadap mahasiswi yang cenderung dipandang sebagai makhluk yang lemah lembut, ulet, rapih dan teliti, secara umum di Fakultas Pendidikan IImu Pengetahuan Sosial diberikan amanah sebagai sekretaris dan bendahara yakni merupakan bagian-bagian dari internal atau dalam konteks gender biasa disebut dengan wilayah domestik, hal itu pun dikarenakan sifat-sifat tersebut dianggap telah melekat di diri mahasiswi sebagai perempuan yang dapat mendukung status dan peran sebagai sekretaris dan bendahara di organisasi yang berkaitan erat dengan hal-hal administratif. Sedangkan status dan peranan sebagai seorang ketua di organisasi yang merupakan bagian wilayah publik lebih ditujukan kepada mahasiswa, hal ini dikarenakan adanya suatu persepsi yang telah melekat pada diri mahasiswa yang diidentikan memiliki jangkauan yang luas, logis dan secara fisik mereka dianggap lebih kuat, energik dan gesit. Hal-hal tersebut menunjukkan adanya ketidakadilan gender yang merupakan hasil persepsi yang stereotip sehingga mensubordinasikan salah satu jenis 
kelamin sebagaimana yang diungkapkan Fakih (2013, hlm.15-21) bahwa manifestasi ketidakadilan gender adalah adanya margninalisasi perempuan dalam wilayah domestik sedangkan laki-laki ke wilayah publik sebagai akibat adanya pandangan gender yang menimbulkan subordinasi dan stereotip sehingga terbentuknya suatu kontruksi sosial terhadap penempatan perempuan di bagian internal (domestik) dan laki-laki di bagian eksternal (publik).

Penelitian

ini

juga

mengungkapkan bahwa mahasiswi memiliki suatu kebebasan dalam memilih status dan perananya didalam organisasi karena sifat-sifat yang melekat di diri mahasiswi dan mahasiswa tidak selamanya sesuai dengan apa yang dipersepsikan pada umumnya. Walaupun secara umum mahasiswi sebagai perempuan selalu diidentikan dengan hal-hal feminim dan wilayah domestiknya begitu pula mahasiswa sebagai laki-laki yang selalu dikaitkan dengan wilayah publik dan sifat maskulinitasnya, tapi ada saja mahasiswi yang memiliki status dan peran di wilayah publik yakni menjadi ketua sedangkan mahasiswa status dan perananya menjadi sekretatis dan bendahara yang merupakan bagian wilayah domestik. Hal tersebut sesuai dengan pemikiran Setiadi dan Kolip (2011, hlm.873) bahwa sifat-sifat yang melekat pada perempuan seperti lemah lembut, dan tidak agresif (feminim) dan laki-laki dengan sifat maskulinnya tidak dapat sepenuhnya digeneralisasikan karena ada saja perempuan bersifat maskulin yakni tidak lemah lembut, agresif, pencari nafkah dan secara de facto sebagai kepala keluarga. Sedangkan laki-laki yang lemah lembut, yang secara de facto bukan pencari nafkah dsb.

\section{Motivasi Mahasiswi dalam Berorganisasi}

Manusia dalam melakukan aktivitas tentu memiliki suatu tujuan yang ingin dicapai. Keinginan tersebut mendorong mereka untuk senantiasa terlibat dalam suatu pergaulan dan melakukan kerjasama agar dapat mencapai tujuan yang hendak dicapai. Dorongan yang muncul untuk mewujudkan tujuan atau cita-cita tersebut secara umum biasanya disebut dengan motivasi. Sedangkan motivasi itu sendiri seperti yang diungkapkan menurut Vroom (dalam Liliweri, 1997, hlm.329) bahwa motivasi adalah dorongan yang merupakan penentu pilihan seseorang dalam melakukan sesuatu atau pekerjaan tertentu sehingga dirinya merasa ringan atau suka rela dalam menjalankan tugas atau pekerjaannya.

Berdasarkan temuan empiris dapat diungkapkan bahwa pada umumnya mahasiswi Fakultas Pendidikan IImu Pengetahuan Sosial turut berperan aktif dalam berorganisasi memiliki motivasi untuk memperoleh pengalaman beroganisasi yang dapat menunjang kegiatan akademik dan sebagai bekal persiapan ketika mereka terjun langsung di masyarakat kelak. Hal tersebut sejalan dengan pokok pemikiran Liliweri (1997) bahwa orang bergabung dalam satu kelompok atau organisasi dan mendukung setiap bentuk kegiatan karena organisasi tersebut dapat memenuhi kebutuhan, 
keinginan, cita-cita mereka, dan merubah kualitas hidup, maka dari itu motivasi dapat pula diartikan sebagai pengharapan sekaligus pendorong seseorang dalam berpartisipasi dengan suatu kelompok.

Motivasi mahasiswi dalam berorganisasi juga dapat ditinjau dari pemikiran Herzberg tentang faktorfaktor yang mempengaruhi motivasi yakni dimana seseorang tidak dapat terlepas dari pengaruh dua faktor di antaranya faktor pemeliharaan (hygiene factors) yang berasal dari internal atau dalam dirinya dan faktor motivasi (motivational factor) yang berasal dari eksternal atau di luar diri manusia (Pujadi, 2007, hlm.43). Pemikiran tersebut sesuai dengan temuan empiris bahwa motivasi mahasiswi dalam berorganisasi di lingkungan Fakultas Pendidikan IImu Pengetahuan Sosial juga mengalami fluktuasi yang dipengaruhi oleh faktor internal yang ada pada dirinya dan faktor eksternal yang merupakan pengaruh dari luar dirinya. Faktor internal tersebut mencakup komitmen pribadi dan faktor biologis (menstruasi). Komitmen pribadi adalah salah satu faktor internal yang dapat dijadikan sebagai landasan atau prinsip personal mahasiswi agar senantiasa terus menjalankan tanggung jawab organisasinya dan komitmen pribadi juga dapat dijadikan sebagai filter dari pengaruh buruk yang berasal dari luar dirinya. Sedangkan faktor biologis dalam konteks ini adalah masa menstruasi, memiliki dampak pengaruh terhadap kondisi fisik mahasiswi yang pada umumnya akan melemah sehingga tidak dapat melakukan berorganisasi secara optimal.

Selanjutnya faktor eksternal atau faktor dari luar dirinya yang dapat mempengaruhi motivasi mahasiswi dalam berorganisasi, yaitu teman sebaya, lingkungan organisasi, dan keluarga. Apresiasi teman sebaya atau teman sepermainan baik itu melalui keikutsertaan mereka dalam kegiatan organisasi maupun terlibat langsung menjadi pengurus organisasi dianggap dapat mempengaruhi fluktuasi mahasiswi dalam berorganisasi, sedangkan lingkungan organisasi yang mencakup kondisi pengurus, pemimpin dan kejelasan agenda organisasi ketiga hal tersebut memiliki keterkaitan, dalam penelitian ini mengungkapkan bahwa kondisi pengurus satu dengan yang lainnya akan saling mempengaruhi, terciptanya kondisi pengurus yang bersemangat dan berkomitmen dalam berorganisasi atau tidaknya, hal tersebut tidak dapat terlepas dari manajemen agenda organisasi karena selain agenda organisasi, mahasiswi juga memiliki agenda kuliah. Sedangkan terkait pemimpin yang menjadi sorotan adalah gaya kepemimpinan dan cara merangkul pengurusnya, hal ini menjadi penting dan bahan perhatian lantaran pemimpin memiliki tanggung jawab atas anggotanya, hal tersebut sesuai dengan sifat organisasi formal yang diungkapkan Asmani (2012, hlm.25) bahwa dalam organisasi formal kedudukan atau jabatan digambarkan seperti tangga atau memiliki tingkatan yang lazim disebut hierarki, dimana setiap orang yang memiliki kedudukan dengan membawahi anggotanya maka 
dia bertanggung jawab atas anggotannya tersebut.

Fluktuasi motivasi mahasiswi dalam berorganisasi tentunya membutuhkan suatu upaya agar mahasiswi tersebut tetap komitmen berorganisasi dan memenuhi tanggung jawabnya sebagai pengurus organisasi tersebut. Paul Meyer membagi motivasi menjadi 3 bentuk di antaranya motivasi yang bersifat mengancam, menakut-nakuti dan memberikan sebuah sanksi, motivasi tersebut dianggap biasa diterapkan dalam organisasi, kemudian motivasi yang dilakukan dengan pemberian insentif dan terakhir adalah motivasi yang diberikan melalui suatu keteladanan/sikap (Liliweri, 1997). Berdasarkan temuan empiris yang memiliki kesesuaian dengan pemikiran Meyer, maka peneliti dapat mengungkapkan bahwa motivasi dalam berorganisasi dapat diklasifikasikan sebagai motivasi yang berasal dari organisasi itu sendiri sebagai upaya meningkatkan motivasi pengurus dan motivasi yang berasal dari dalam diri atau internal pengurus tersebut.

Selanjutnya dalam rangka mengembalikkan semangat dan motivasi berorganisasi pengurus, organisasi mahasiswa yang ada di lingkungan Fakultas Pendidikan IImu Pengetahuan sosial, menyediakan beberapa program yang biasanya di kelola oleh bidang keorganisasian yakni Sanksi dan Upgrading. Sanksi merupakan salah satu program untuk menertibkan pengurus yang dianggap telah melalaikan tanggung jawab sesuai dengan ketentua-ketentuan yang ada di dalam Standar
Operasional Prosedur (SOP) organisasi, apabila ditinjau melalui pemikiran Meyer maka program ini termasuk ke dalam motivasi yang berbentuk ancaman dan menakutnakuti/pemberian sanksi, pasalnya, adanya sanksi tersebut tentu begitu dihindari oleh pengurus karena sanksi tersebut diidentikkan dengan pengurus yang tidak prestatif dalam arti melalaikan tanggung jawabnya sebagai pengurus sehingga sanksi tersebut dapat menjadi dorongan agar senantiasa komitmen berorganisasi dan melaksanakan tanggung jawab sebagai pengurus. Sedangkan motivasi yang sifatnya insentif terdapat pada program upgrading melalui kegiatan ini pengurus diberikan hadiah berupa kesempatan untuk berekreasi bersama dengan pengurus lainnya untuk sejenak melepas penat selama berorganisasi, yang kemudian dilanjut dengan proses komunikasi terbuka atau evaluasi bersama terkait kepengurusan organisasi dan persoalan yang dihadapi selama kepengurusan dengan harapan setelah program ini pengurus dapat kembali termotivasi untuk terus berkomitmen dalam berorganisasi.

Adanya program sanksi sebagai motivasi bersifat ancaman atau punishment dan upgrading sebagai motivasi yang bersifat insentif atau reward dalam organisasi mahasiswa juga sesuai dengan pemikiran Weber bahwa organisasi yang baik harus memiliki suatu mekanisme berupa reward dan punishment (Liliweri, 1997, hlm.6). Disamping adanya upaya meningkatkan motivasi pengurus dari lembaga atau organisasi, ada juga upaya yang dilakukan dari internal 
mahasiswi itu sendiri, yakni dengan bersikap terbuka, baik itu melalui evaluasi diri sendiri atau instrospeksi maupun diskusi dengan senior atau pengurus terhdahulu yang dianggap mengerti persoalan organisasi agar mendapatkan masukan atau saransaran yang dapat dijadikan bahan evaluasi diri yang dianggap dapat mengembalikkan semangat berorganisas. Apabila ditinjau pada pemikiran Meyer tentang motivasi berorganisasi, maka hal tersebut mengacu kepada motivasi berupa keteladanan/sikap, karena memang mahasiswi mencoba tidak menutup diri dari kritikan dengan memberikan keteladanan dengan sikap terbuka terhadap kritik dan saran yang membangun agar dapat dijadikan bahan pertimbangan evaluasi atau introspeksi diri mahasiswi tersebut.

\section{Aksesibilitas Mahasiswi dalam Menempati Posisi Strategis di Organisasi}

Berdasarkan temuan empiris, peneliti dapat mengungkapkan bahwa aksesibilitas mahasiswi dalam memperoleh posisi strategis terbilang terbuka tidak ada salah satu jenis kelamin dianggap istimewa semuanya dianggap sama karena memang dalam penyelenggaraan organisasi kemahasiswaan sudah diatur dalam Peraturan Rektor Universitas Pendidikan Indonesia Nomor : 8052 $/ \mathrm{H} 40 / \mathrm{HK} / 2010$ tentang Organisasi Kemahasiswaan di Lingkungan Universitas Pendidikan Indonesia pada pasal 2 ayat 1, bahwa organisasi kemahasiswaan haruslah memiliki prinsip terbuka untuk semua kalangan baik itu mahasiswa atau mahasiswi dan tidak diskriminatif, yakni tidak membeda-bedakan mahasiswi atau mahasiswi. Adapun dalam kehidupan berorganisasi di lingkungan Fakultas Pendidikan IImu Pengetahuan Sosial, mahasiswi dan mahasiswa memiliki kebebasan berkompetisi untuk memperoleh posisi-posisi strategis di organisasinya selama kompetisi tersebut sehat dan tidak melanggar prosedur yang telah diatur dalam ketentuan-ketentuan organisasi. Hal tersebut sesuai dengan pokok pemikiran feminisme liberal yang diungkapkan John Stuart Mill bahwa setiap orang memiliki suatu kebebasan untuk memperoleh apa yang dikehendaki atau yang diinginkanya selama apa yang dikerjakannya dalam mewujudkan keinginanya tersebut tidak membatasi atau menghalangi orang lain (Tong, 1998.hlm23).

Kesempatan dan kebebasan mahasiswi dalam menduduki posisi strategis bukan lantas membebaskan mahasiswi dari tuntutan atas kriteriakriteria tertentu untuk menduduki posisi strategis sebagai bahan pertimbangan. Kriteria-kriteria tersebut mencakup potensi atau kemampuan dalam berorganisasi, prestasi, dan dukungan dari orang-orang sekitarnya. Kemampuan berorganisasi ini tidak terlepas dari pemahaman terhadap tugas dan pokok serta fungsi dari organisasi, cara berpikir dalam membuat suatu konsep, pemahaman terhadap regulasi organisasi dan kecakapan berkomunikasi, sedangkan terkait prestasi baik itu secara akademik maupun non akademik dianggap perlu lantaran dalam menduduki posisi strategis karena secara umum dalam regulasi setiap 
organisasi yang berada di Lingkungan Fakultas Pendidikan IImu Pengetahuan Sosial dijadikan salah satu syarat penting apabila seseorang ingin menduduki posisi strategis terlebih lagi menjadi seorang ketua. Kompetensi dan prestasi seseorang akan lengkap apabila adanya dukungan dari orang-orang di sekitarnya, hal tersebut menunjukan bahwa kompetensi dan prestasinya dapat dipertimbangkan dan layak dipercaya untuk menduduki posisi strategisnya.

Merujuk dari pemaparan hasil temuan empiris tersebut dapatlah sejalan dengan pokok pemikiran feminisme liberal tentang kesamaan hak antara laki-laki dan perempuan lantaran keduanya memiliki potensi rasionalitas yang sama. Seperti yang diungkapkan Wollstonecraft (dalam Tong,1998, hlm.20) bahwa antara perempuan dan laki-laki sebagai manusia merupakan makhluk yang memiliki nalar karena potensi dan kapasitas tersebut merupakan kekhasan manusia yang membedakan manusia dengan makhluk lainnya. Relevansi ini berkenaan dengan adanya tuntutan atas kriteria apabila seseorang ingin menduduki posisi strategis terlepas itu mahasiswi atau mahasiswa tidak ada pengecualian yakni mereka harus memenuhi kriteria yang telah ditentukkan agar dapat dipertimbangkan untuk memperoleh posisi strategis yang diinginkanya. Selain itu juga relevansi tersebut dapat ditinjau dari adanya persamaan tuntutan atau krtieria tertentu atas intelektualitas baik itu mahasiswi atau mahasiswa yang diatur dalam regulasi organisasi apabila seseorang ingin menduduki posisi strategis biasanya hal tersebut ditunjukan melalui Indeks Prestasi Kumulatif (IPK). Berdasarkan hasil temuan empiris, bahwa dalam organisasi kemahasiswaan ada agenda penting yakni Musyawarah Mahasiswa (MUMAS) untuk merumuskan segala sesuatu terkait organisasi kedepannya hal tersebut sebagaimana sifat organisasi formal menurut Asmani (2012,hlm.25) yakni memiliki suatu anggaran dasar dan anggaran rumah tangga sebagai landasan penyelenggaraanya yang biasanya ditentukan dalam musyawarah yang mufakat. Selain itu sebagai kelompok yang mendominasi secara kuantitas dalam berorganisasi di lingkungan Fakultas Pendidikan IImu Pengetahuan Sosial mereka memiliki kesempatan terbuka untuk berpartisipasi dalam forum tertinggi yakni Musyawarah Mahasiswa atau Sidang Umum untuk menentukan regulasi atau kebijakan-kebijakan untuk organisasinya yang akan datang. Hal tersebut sejalan dengan pemikiran feminisme liberal yakni menciptakan kesetaraan gender dengan membebaskan perempuan dari peran gender yang memposisikan dirinya sebagai pihak kedua atau posisi yang lebih rendah dalam suatu kegiatan seperti akademi, forum, maupun pasar (Tong, 1998,hlm.48).

Pada bagian ini menunjukan bahwa mahasiswi sudah memiliki sebuah akses yang terbuka dalam menentukan suatu regulasi atau keputusan yang dapat mempengaruhi kebijakan di organisasinya terlepas dari adanya stereotip tentang dirinya sebagai perempuan hal ini juga sebagai bukti adanya kebebasan dan 
kesetaraan gender di dalam organisasi yang berada di lingkungan Fakultas Pendidikan IImu Pengetahuan Sosial sesuai dengan konsep kesetaraan gender Miftahuddin dkk. (2011, hlm.4) bahwa kesetaraan gender adalah suatu keadaan dimana antara laki-laki dan perempuan sebagai manusia tidak memiliki perbedaan dalam memperoleh haknya secara penuh, melainkan keduanya memiliki kapasitas yang setara atau sama untuk memperoleh haknya baik itu dalam bidang sosial, ekonomi, politik dan hukum.

Aksesibilitas mahasiswi dalam berorganisasi dalam konteks untuk menjadi seorang pemimpin dalam sebuah organisasi tidak dijadikan masalah, hal tersebut ditanggapi positif karena hal tersebut dianggap dapat dijadikan ajang aktualisasi dan eksistensi bahwa mahasiswi juga mampu memimpin organisasi. Kendati mahasiswi mendapat tanggapan positif untuk menjadi seorang pemimpin. Namun bukan berarti mereka tidak dihadapkan sebuah hambatan sosial budaya seperti adanya stereotip hasil konstruksi sosial yakni pemimpin identik dengan sifat-sifat maskulin yang dimiliki mahasiswa. Hal tersebut sesuai dengan pokok pemikiran yang disampaikan Handayani dan Sugiharti (2008, hlm.8), bahwa kepemimpinan dan kekuasaan bagaikan dua sisi gambar dalam mata uang koin, dimana keduanya tidak dapat dipisahkan, keduanya tidak pernah diidentikkan dengan sifat-sifat dasar feminim seperti lemah lembut dan tidak umum tampil sebagai pemimpin yang acap kali mengarah pada sifatsifat yang dimiliki perempuan, melainkan kepemimpinan dan kekuasaan dipersepsikan sebagai bagian dari laki-laki yang dicirikan atau diasosiasikan dengan kejantanan, ketegasan, keberanian, kemandirian, dan kekuatan fisik dimana hal-hal tersebut identik dengan sifat dasar maskulinitas yang dimiliki laki-laki.

Aksesibilitas mahasiswi untuk memperoleh posisi sebagai pemimpin kadangkala terbentur dengan nilai-nilai tradisional yang memang sudah melekat dalam konstruksi sosial budaya masyarakat. Begitu pula dalam kehidupan berorganisasi di kalangan mahasiswa dan mahasiswi yakni mahasiswi memiliki suatu kecenderungan lebih mendahulukan mahasiswa dibandingkan mahasiswi dengan catatan mahasiswa tersebut memiliki kompetensi yang mumpuni sebagai pemimpin, hal tersebut sejalan dengan pokom pemikiran yang disampaikan oleh Sopiah (2011.hlm17) bahwa tidak adanya pemberian atribut kepemimpinan dan kekuasaan terhadap perempuan bukan saja dilakukan oleh masyarakat pada umumnya melainkan hal tersebut juga dipengaruhi oleh perempuan itu sendiri yang tidak memberikan atribut kekuasaan kepada kaum perempuan. $\mathrm{Hal}$ ini juga diperkuat dengan adanya hasil temuan empiris yang menunjukkan bahwa dari 11 Himpunan yang berada di lingkungan Fakultas Pendidikan IImu Pengetahuan Sosial semuanya adalah laki-laki (mahasiswa).

Konstruksi sosial yang telah melekat pada diri perempuan nampaknya juga membawa pengaruh terhadap kepemimpinan perempuan begitu pula dalam konteks 
kepemimpinan mahasiswi di dalam organisasi kampus. Persepsi yang melekat ketika mahasiswi menjadi seorang pemimpin yakni memiliki suatu kelemahan yakni seperti ketidaktegasan dan memiliki langkah yang terbatas. Suatu anggapan yang muncul dari konstruksi yang ada ialah mahasiswi selalu identik dengan sifatsifat yang feminim seperti yang diungkapkan oleh Handayani dan Sugiharti (2008,hlm.8) bahwa perempuan dengan feminimnya identik dengan kurang jelas menyampaikan sesuatu atau bertele-tele, sukar dalam mengatasi persoalan, sukar dalam membedakan rasio dan rasa, dan kurang independen atau kurang merdeka. Apabila diamati pemikiran Handayani dan Sugiharti memiliki relevansi dengan hasil temuan empiris bahwa mahasiswi yang menjadi pemimpin dalam organisasinya dianggap tidak memiliki ketegasan karena dikhawatirkan keputusannya menyinggung salah satu pihak sehingga mahasiswi dianggap sukar untuk mengatasi persoalan yang ada diorganisasinya. Selain itu mahasiswi juga memiliki langkah yang terbatas karena memang kegiatan organisasi tidak hanya dari pagi sampai sore, melainkan bisa sampai malam bahkan sampai menginap, keterbatasan tersebut dianggap suatu kelemahan dimana apabila merujuk pada pemikiran Handayani dan Sugiharti mencerminkan bahwa mahasiswi kurang merdeka karena mereka tidak dapat sepenuhya mengikuti kegiatan organisasi.

Disamping itu ketika mahasiswi menjadi seorang pemimpin ia dapat memanfaatkan sifat-sifat feminimnya seperti teliti, ulet, rapih, dan sistematis sehingga mereka dianggap memiliki sautu kelebihan apabila memimpin yakni salah satunya manajemen administrasi kendati hal tersebut lebih identk dengan tugas sekretaris namun dengan kemampuannya tersebut mahasiswi dapat memberikan contoh, arahan kepada anggotanya tentang administrasi dan menyelesaikan halhal yang berkaitan dengan administrasi apabila ada suatu persoalan dalam administrasi di organisasinya karena memang kegiatan organisasi di kampus tidak dapat terlepas dari administrasi. Selain itu mahasiswi juga dianggap memiliki kelebihan yakni etos kerja yang tinggi karena seperti yang telah disampaikan oleh Handayani dan Sugiharti tentang sifat-sifat feminim yang dianggap melekat di diri mahasiswi sebagai perempuan menjadikan mereka harus menggunakan strategi lain untuk mengatasi keterbatasan langkah yang memang sudah jadi konstruksi sosial tersebut, yakni dengan memanfaatkan waktu seoptimal mungkin sehingga mereka memiliki etos kerja yang tinggi dengan bekerja multitasking hal ini tidak terlepas dari kecenderungan bahwa perempuan dianggap dapat mengerjakan urusan domestik yang begitu menumpuk hal tersebut sesuai dengan pokok pemikiran yang disampaikan oleh Fakih (2013, hlm.15-21), bahwa adanya suatu anggapan atau persepsi yang berkembang di masyarakat, kaum perempuan memiliki sifat pemelihara dan rajin sehingga hal-hal yang berkaitan dengan domestik rumah tangga perempuanlah yang menjadi penanggung jawab utama sehingga 
mereka cenderung harus bekerja kerasa dengan tugas-tugas domestik yang begitu menumpuk seperti membersihkan dan mengepel lantai, memasak, mencuci, mencari air untuk mandi hingga memelihara anak. Dengan demikian dari sudut pandang lain hal tersebut dapat dijadikan suatu kelebihan mahasiswi yang dianggap sudah terbiasa dengan segudang tugas domestik sehingga mereka memiliki etos kerja yang tinggi tatkala dihadapkan menjadi seorang pemimpin di organisasisnya. Selanjutnya berdasarkan hasil temuan empiris bahwa kelebihan lain yang dimiliki mahasiswi menjadi pemimpin adalah memiliki empati yang tinggi terhadap anggotanya hal ini dianggap suatu kelebihan lantaran di organisasi sarat sekali konflik, maka melalui empati yang dimilikinya mereka dianggap bisa lebih peka terhadap persoalan yang menimpa anggotanya sehingga mereka dapat memanfaatkan hal tersebut untuk melakukan pendekatan personal kepada anggotanya guna mencari penyebab dari persoalan yang menimpa anggotanya.

Apabila diamati lebih mendalam kelebihan yang dimiliki mahasiswi ini tidak terlepas dari memanfaatkan konstruksi sosial yang melekat pada dirinya sehingga mereka memiliki gaya kepemimpinannya sendiri dalam memimpin suatu organisasi. Hal tersebut merujuk pada pemikiran Sopiah (2011,hlm.18) Apabila perempuan ingin tampil sebagai pemimpin maka ia tidak harus berusaha seperti laki-laki dengan menunjukkan sifat maskulin melainkan ia dapat memimpin dengan gayanya sendiri yakni dengan sifat feminim yang dimilikinya seperti pendekatan kasih sayang, keibuan dan penuh perhatian dalam menjalankan kepemimpinannya. Dengan demikian dilihat dari sudut pandang lain, kelebihan yang dimiliki mahasiswi tidak terlepas dari upaya mengatasi hal-hal yang telah dianggap suatu kelemahan yang melekat pada dirinya sebagai pemilik sifat feminim, sehingga mereka dapat memanfaatkan sisi perempuannya tatkala dijadikan seorang pemimpin di organisasi.

\section{Kendala yang Dihadapi Mahasiswi dalam Berorganisasi dan Upaya Mahasiswi untuk Mengatasi Kendala}

Mahasiswi dalam berorganisasi tidak selamanya berjalan mulus mereka juga dihadapkan beberapa kendala. Berdasarkan hasil temuan empiris ada beberapa kendala yang sering ditemui oleh mahasiswi di Lingkungan Fakultas Pendidikan IImu Pengetahuan Sosial di antaranya (1)Faktor biologis (menstruasi) Langkah yang terbatas dan (3) Konflik

Faktor biologis (menstruasi) yang dialami perempuan merupakan suatu hal yang wajar karena hal tersebut adalah kodrat dari jenis kelamin perempuan yang secara alamiah akan mengalami fase menstruasi. Hal tersebut sesuai dengan pernyataan Narwoko dan Suyanto (2007, hlm.333) bahwa secara biologis kodrat yang melekat pada diri laki-laki dan perempuan itu berbeda, perempuan memiliki alat reproduksi seperti rahim, vagina, payudara, dan reproduksi lainnya sehingga mereka mengalami 
fase menstruasi, mengandung dan melahirkan. Menstruasi adalah salah satu kendala mahasiswi dalam berorganisasi lantaran ketika mereka menstruasi kondisi badan melemah dan tak jarang mereka akan menjadi lebih moody sehingga mereka ketika berorganisasi tidak dapat optimal. Hal tersebut sesuai dengan pernyataan yang diungkapkan Maslow (dalam Goble, 1987,hlm.72) bahwa kebutuhan seseorang seperti piramida yang memiliki suatu tingkatan-tingkatan dimana kebutuhan fisiologis menjadi kebutuhan yang paling mendasar dari kebutuhan-kebutuhan lain, dan apabila kebutuhan fisiologis ini tidak terpenuhi akan berdampak pada tingkah laku seseorang dan kebutuhan lainnya.

Selanjutnya yang menjadi suatu hambatan bagi mahasiswi adalah langkahnya yang terbatas. Secara umum konstruksi sosial yang ada menyudutkan mahasiswi agar senantiasa pulang tidak sampai larut malam, karena sebagai perempuan dianggap kurang baik dan dapat membahayakan dirinya apabila pulang terlalu larut malam sedangkan di satu sisi kegiatan organisasi bisa sampai larut malam dan bahkan menginap. Hal tersebut sesuai dengan pernyataan yang diungkapkan oleh Sopiah (2011,hlm.48-49) bahwa kontruksi sosial budaya masyarakat Indonesia masih tradisional dimana perempuan dipersepsikan sebagai pendamping yang harus dilindungi sehingga mereka memiliki keterbatasan dalam berpartisipasi dalam bidang. Begitu pula dengan mahasiswi dalam berorganisasi sebagai perempuan mereka mengalami hambatan bahwa mereka pada umumnya tidak diperbolehkan pulang larut malam baik itu dari orangtua, sanak saudara maupun pemilik kots sehingga mereka memiliki keterbatasan untuk mengikuti kegiatan organisasi sampai larut malam.

Konflik dalam berorganisasi turut menjadi kendala mahasiswi dalam berorganisasi. Adapun dari hasil temuan empiris mahasiswi kerap kali dihadapkan dengan konflik internal dirinya seperti konflik peran. Sedangkan konflik peran itu sendiri yakni kondisi seseorang yang dihadapkan dengan benturan atas peran-peranya yang menuntut pemenuhan kewajiban secara bersamaan. (Henslin, 2007, hlm.107). Hal tersebut juga terjadi pada mahasiswi, di satu sisi ia memiliki tanggung jawab terhadap tugas kuliah sebagai sivitas akademik sedangkan di sisi lain ia harus bertanggung jawab terhadap tugas-tugas atau amanah dari organisasisnya, hal ini kerap kali terjadi pada mahasiswi sehingga mereka harus memilih salah satu yang menjadi prioritas utama.

Disamping itu mereka juga dihadapkan dengan konflik antar pengurus, yakni dimana hal tersebut dipicu karena adanya perbedaan pendapat yang tidak berujung baik itu dalam mengkonsepkan suatu kegiatan atau hal-hal lain yang berkaitan dengan organisasinya. Hal tersebut sesuai dengan pokok pemikiran Liliweri, (2005, hlm.265-266) bahwa konflik antar pengurus atau biasa disebut konflik antar personal (interpersonal conflict) suatu kondisi dimana adanya ketidakharmonisan antar individu dalam organisasi yang disebabkan adanya ketegangangan 
dalam hubungan antar indvidu individu terhadap persoalan tertentu. Adapun upaya mereka dalam menghadapi kendala-kendala seperti untuk urusan pribadi seperti menstruasi mereka memilih untuk meminum obat atau jamu yang sekiranya memang dapat meringankan nyeri atau menyegarkan kondisi badan. Selain itu juga mereka berusaha untuk tetap komitmen dengan tanggung jawabnya, mencoba profesional yakni memisahkan urusan pribadi dengan urusan organisasi. Selanjutnya terkait langkah yang terbatas, mereka melakukan suatu upaya yakni dengan berkoordinasi untuk membagi tugas dengan pengurus lain, tentunya tugas yang dipilih mereka adalah tugas-tugas yang sekiranya dapat mereka kerjakan dengan situasi dan kondisi yang mereka hadapi, singkatnya mereka melakukan kerjasama dalam berorganisasi agar dalam keterbatasan tersebut mereka tetap bisa berkontribusi. Upaya yang dilakukan mahasiswi seperti komitmen dengan tanggung jawabnya, berkoordinasi untuk membagi tugas dan bekerjasama merupakan suatu cerminan asas atau prinsip dalam berorganisas sebagaimana yang disampaikan Suwatno dan Donni (2012,hlm.61) bahwa dalam berorganisasi setidaknya ada beberapa prinsip atau asas tertentu yang dapat menjadi pegangan dalam menjalankan organisasi antara lain tanggung jawab, pembagian tugas, kejelasan tujuan organisasi dan asas koordinasi, hal-hal tersebut menjadi prinsip berorganisasi agar mencapai tujuan organisasi. Adapun Liliweri (1997, hlm.2) juga mengungkapkan bahwa manusia organisasi atau organisatoris adalah mereka yang memiliki suatu kesadaran bahwa dengan bekerjasama dalam berorganisasi mereka dapat mencapai tujuannya. Merujuk dari pernyataan Liliweri tersebut, mahasiswi dapat dikatakan manusia organisasi yakni ditinjau dari kemauan dan kesungguhan dengan ditunjukkan melalui tanggung jawabnya sebagai seorang pengurus sekalipun dalam kondisi keterbatasan langkah, dan melakukan kerjasama dengan pengurus lain guna mengatasi keterbatasannya sehingga mereka dapat tetap berkontribusi di organisasinya.

Disamping itu perihal konflik peran karena mahasiswi memiliki peran ganda yakni sebagai seorang pengurus di organisasi sedangkan di satu sisi juga sebagai sivitas akademik, terkait hal itu upaya yang dilakukan oleh mahasiswi yakni mereka berkomitmen sebisa mungkin membagi waktu antara peran keduanya, ketika mereka sedang tidak ada tanggung jawab organisasi mereka mengerjakan tugas akademik secara bertahap dan berusaha menghindari kebiasaan menumpuk tugas kuliah, dan ketika memang ada tanggung jawab atau tugas di organisasi, mereka berusaha untuk memenuhi tugas-tugas yang merupakan bentuk tanggung jawabnya sebagai pengurus organisasi, penekanan dari upaya mereka yakni melakukan manajemen waktu sesuai skala prioritas. Hal tersebut sesuai dengan apa yang diungkapkan Henslin 
(2007,hlm.107) bahwa upaya agar berhasil terhindar dari konflik yakni dengan mengatur peran-peran tersebut secara prioritas dan memenuhi tuntutan peran dengan sigap.

Selanjutnya perihal konflik yang terjadi antar pengurus mereka lebih memilih untuk mencari tahu akar persoalan dari konflik tersebut dan kemudian didiskusikan bersama pihakpihak yang berkonflik menemukan penyelesaian yang disepakati bersama. Hal ini termasuk gaya penyelesaian konflik secara kolaboratif atau bekerjasama sebagaimana disampaikan Pickering (2006, hlm.3842) bahwa penyelesaian masalah melalui kerjasama ditandai adanya pencariaan informasi dan diskusi bersama guna terjadi pertukaran informasi tekait perbedaan antara pihak-pihak yang berkonflik dan mencari penyelesaian sesuai dengan kesepakatan bersama. Adapun selain mengadakan diskusi bersama mereka juga melalui upaya lain apabila hal tersebut tidak dapat menyelesaikan persoalan yakni dengan memunculkan pihak ketiga sebagai mediator yang dianggap berwenang dan dapat menyelesaikan masalah. Upaya-upaya penyelesaian konflik antar pengurus ini juga dapat dikatakan sebagai gaya menang/menang sesuai dengan yang diungkapkan Benfari (dalam Sudarmanto, 2014, hlm.157) bahwa kedua belah pihak berusaha mencari penyelesaian masalah dengan bijaksana dimana masing-masing pihak ingin menghasilkan suatu solusi yang dapat bermanfaat bagi semua pihak.

\section{SIMPULAN}

Peran mahasiswi dalam berorganisasi di lingkungan Fakultas Pendidikan Indonesia, pada umumnya keberadaan dan peran mahasiswi dalam berorganisasi sama pentingnya dengan keberadaan dan peran mahasiswa dalam berorganisasi, keduanya saling melengkapi untuk perkembangan organisasi. Peran mahasiswi juga tidak terlepas dari sosialisasi yang diterima yakni melalui serangkaian kaderisasi yang ada di organisasinya. Mahasiswi dalam berorganisasi memiliki suatu kebebasan untuk memilih peranannya dalam beroganisasi selama mereka memiliki kompetensi dalam peran yang dipilihnya. Kendati demikian mereka juga belum bisa sepenuhnya terhindar dari streotipe yang merupakan suatu kontruksi sosial budaya yang secara umum mengidentikkan mahasiswi sebagai perempuan memiliki sifat-sifat feminim yang dianggap lebih cocok untuk peran sebagai sekretaris dan bendahara.

Motivasi mahasiswi Fakultas Pendidikan IImu Pengetahuan Sosial ikut serta dalam organisasi, secara umum untuk memperoleh pengalaman beroganisasi yang dapat menunjang kegiatan akademik dan bekal ketika mereka langsung terjun di masyarakat. Motivasi mahasiswi dalam berorganisasi mengalami fluktuasi yang dipengaruhi faktor intrinsik di antaranya menstruasi dan komitmen pribadi sedangkan faktor ekstrinisik seperti lingkungan organisasi yang mencakup kondisi pengurus, gaya kepemimpinan, dan kejelasan agenda organisasi, teman sebaya dan motivasi dari keluarga. Adapun upaya yang 
dilakukan untuk meningkatkan motivasi baik itu dari organisasi maupun internal mahasiswi sebagai pengurus. Upaya yang dilakukan organisasi yakni melalui motivasi yang bersifat insentif seperti melalui program upgrading yaitu dengan memberikan kesempatan bagi pengurus untuk berekreasi melepas penat tentang organisasi. Selain itu juga ada motivasi yang bersifat mengancam dan menakut-nakuti yakni melalui Sanksi bagi pengurus yang melalaikan tanggung jawabnya. Adapun upaya yang dilakukan internal mahasiswi, yaitu dengan bersikap terbuka terhadap saran dan kritik yang membangun sebagai bahan evaluasi diri guna perbaikan diri dan mengembalikan semangat berorganisasi.

Aksesibilitas mahasiswi dalam memperoleh posisi strategis dapat dikatakan terbuka lantaran antara mahasiswi dan mahasiswa memiliki kesempatan dan kebebasan dalam berkompetisi untuk memperoleh posisi strategis selama tidak melanggar ketentuan-ketentuan di organisasi dan memang tidak ada regulasi yang bersifat mendiskriminatifkan baik itu mahasiswi maupun mahasiswa. Kemudahan aksesibilitas mahasiswi juga ditentukan kompetensi berorganisasi, prestasi yang dimiliki dan dukungan dari orang-orang sekitar. Kriteria tersebut berlaku baik bagi mahasiswi maupun mahasiswa apabila mereka ingin menduduki posisi strategis. Mahasiswi juga memiliki akses terbuka untuk menentukan regulasi organisasinya pada forumforum tertinggi di organisasinya. Mahasiswi memiliki tanggapan posistif untuk menduduki posisi strategis di organisasinya karena memang tidak ada regulasi yang membatasi mahasiswi untuk mendapat aksesibilitasnya menduduki posisi strategis seperti ketua. Pada implementasinya walaupun kompetensi seseorang dalam berorganisasi menjadi bahan pertimbangan untuk menduduki posisi strategis dan tidak ada regulasi yang diskriminatif. Namun masih saja didapati pengaruh nilai-nilai tradisional yang streotipe terhadap posisi ketua yang diidentikan dengan sifat-sifat maskulinitas laki-laki dan bersifat patriaki yang mendahulukan laki-laki (mahasiswa) untuk menjadi pemipin atau ketua. Kendala yang dihadapi mahasiswi dalam beroganisasi di antaranya adalah menstruasi, keterbatasan langkah dan konflik. Menstruasi dianggap dapat menjadi kendala dalam beroraganisasi lantaran mempengaruhi terhadap kondisi fisik atau kondisi badan yang cenderung melemah sehingga mereka merasa tidak dapat optimal dalam beroganisasi. Kegiatan organisasi kampus tidak hanya pagi, siang atau sore melainkan bisa sampai malam dan bahkan menginap sedangkan di satu sisi mahasiswi memiliki keterbatasan langkah karena mereka tidak bisa mengikuti kegiatan organisasi sepenuhnya sampai larut malam, maka dari itu hal tersebut dianggap menjadi suatu kendala bagi mahasiswi dalam berorganisasi. Selain itu konflik juga turut menjadi kendala baik itu konflik peran maupun konflik antar pengurus. Konflik peran karena memiliki peran ganda, yaitu di satu sisi harus menyelesaikan tugas 
akademiknya sebagai sivitas akademik sedangkan di satu sisi mereka dihadapkan dengan tugas organisasi sebagai pengurus organisasi tersebut sedangkan konflik antar pengurus biasanya dipicu oleh adanya perbedaan pendapat ketika dalam forum atau mengkonsepkan kegiatan. Adapun upaya mereka untuk mengatasi kendala tersebut, meminum obat atau jamu pereda nyeri yang dapat meringankan menstruasi, melakukan kerjasama dengan pengurus lain dan pembagian tugas yang memungkinkan dikerjakan dalam kondisinya tersebut sebagai upaya mengatasi keterbatasan langkahnya, terkait konflik peran mereka menggunakan skala prioritas dan menghindari menumpuk tugas. Sedangkan konflik antar pengurus melalui pendekatan gaya menang/menang guna mendapatkan penyelesaian yang disepakati dan bermanfaat bagi semua pihak.

\section{DAFTAR RUJUKAN}

\section{Buku:}

Abercrombie, Nicholas., Hill Stephen., \& Turner, Bryan S. (2010). Kamus Sosiologi. Yogyakarta: Pustaka Pelajar.

Asmani, J.M. (2012). Tips Sakti Membangun Organisasi Sekolah. Yogyakarta: Diva Press.

Bungin, B. (2011b). Metodologi Penelitian Kualitatif. Jakarta : Kencana.

Fakih, M. (2013). Analisis Gender dan Transformasi Sosial. Yogyakarta: Pustaka Pelajar.

Handayani, $T$ dan Sugiharti, (2008).Konsep dan Teknik
Penelitian Gender, Malang: UMM Press.

Henslin, M.J (2007) Sosiologi dengan

Pendekatan Membumi. Jakarta: Erlangga.

Liliweri, A.(1997). Sosiologi Organisasi. Bandung: PT.Citra Aditya Bakti.

Liliweri, A.(2005). Prasangka dan Konflik: Komunikasi Lintas Budaya Masyarakat Multikultural. Yogyakarta: Lkis.

Narwoko, D.J. \& Suyanto, B (2007). Sosiologi: Teks Pengantar dan

Terapan. (edisi kedua). Jakarta: Kencana.

Pickering,P.(2006).How To Manage Conflict: Kiat Menangani Konflik.Jakarta: Erlangga.

Setiadi, E.M \& Kolip,U. Pengantar

Sosiologi. (2011). Jakarta:

Kencana.

Sopiah, Pipih.(2011). Inspirasi untuk

Perempuan Berpolitik. Bandung:

CV Bangkit Citra Persada.

Sudarmanto.(2014).Kinerja dan

Pengembangan Kompetensi SDM.

Yogyakarta: Pustaka Pelajar

Sugiyono. (2009c). Memahami

Penelitian Kualitatif. Bandung :

Alfabeta.

Suwatno \& Donni J.P.(2012). Dasar-

Dasar Manajemen dalam

Berorganisasi Pulik dan Bisnis.

Bandung: UPI PRESS.

Tong, P.R.(1998). Feminist Thought:

Pengantar Paling Komprehensif kepada Arus Utama Pemikiran Feminis. Yogyakarta: Jalasutra.

\section{Jurnal:}

Astuti, P. (2013). Peluang PNS Perempuan dalam Memperoleh Jabatan Struktural: Studi Kualitas 
Kesetaraan Gender di Pemerintah Kota Semarang. POLITIKA: Jurnal IImu Politik, 3(2),68-83.

Pujadi,A.(2007). Faktor-Faktor yang Mempengaruhi Motivasi Belajar Mahasiswa: Studi Kasus Pada Fakultas Ekonomi Universitas Bunda Mulia. Business \& Management Journal Bunda Mulia, volume 3 (2). hlm.40-51.

Wahyuni, S \& Hidayah, N.(2014).

Partisipasi Perempuan dalam Organisasi Ikatan Pelajar Mahasiswa Riau Kabupaten Pelalawan (IPMR-KP) di Yogyakarta. E-Societas, 3 (7), hlm. 1-12.

\section{Skripsi dan Laporan:}

Aritonang, Juneris. (2010). Hubungan

Budaya Patriaki Terhadap Keputusan WUS Menjadi Akseptor Keluarga Berencana di Lingkungan VI Simpang Selayang Medan Tuntungan. Medan: Universitas Sumatera Utara

Miftahuddin, dkk.(2008). Laporan Penelitian Tentang Sensitivitas dan Aplikasi Kesetaraan Gender di Organisasi Kemahasiswaan Universitas Negeri Yogyakarta. Yogyakarta: Universitas Negeri Yogyakarta.

\section{Peraturan/Perundang-undangan:}

Peraturan Rektor Universitas
Pendidikan Indonesia Nomor:
8052/H40/HK/2010 tentang
Organisasi Kemahasiswaan di
Lingkungan Universitas Pendidikan
Indonesia Pasal 4 ayat 1.

